Research Article / Araştırma Makalesi

\title{
FACTORS AFFECTING EXTERNAL DEBT IN TRANSITION ECONOMIES: THE CASE OF CENTRAL ASIA AND THE CAUCASUS*
}

\author{
Asst. Prof. Ersin Nail SAĞDIÇ*** (D) \\ Kütahya Dumlupınar University, FEAS, Kütahya,Turkey, (ersinnailsagdic@dpu.edu.tr)
}

Assoc. Prof. Fazlı YILDIZ (D)

Kütahya Dumlupınar University, FEAS, Kütahya, Turkey, (fazli.yildiz@dpu.edu.tr)

\begin{abstract}
This study is to examine the key factors affecting external debts for the Central Asia and the Caucasus economies between the years 1995-2017 by using panel data analysis. Panel regression results show that public expenditures and the debt service have positive effect on external debt, while current account of the balance, inflation rate and domestic savings have a negative, and also significant effect on external debt. The results of this study show that foreign debt is being used as a significant source of financing for public expenditures, foreign debt repayments, and the current account deficit in the countries of Central Asia and the Caucasus.
\end{abstract}

Keywords: External Debt, Panel Data Analysis, Transition Economies, Central Asia and the Caucasus Economies.

\section{GEÇIŞ EKONOMILERİNDE DIŞ BORÇLANMAYI ETKİLEYEN FAKTÖRLER: ORTA ASYA VE KAFKAS ÜLKELERİ ÖRNEĞİ}

\begin{abstract}
ÖZET
Bu çalışmada, Orta Asya ve Kafkas ekonomileri için 1995-2017 yılları arasında panel veri analizi kullanılarak dış borçları etkileyen temel faktörler incelenmektedir. Panel regresyon bulguları; kamu harcamaları ve borç servisinin dış borçlanmayı pozitif yönde etkilediği ve istatistiksel olarak anlamlı etkiye sahip olduğunu göstermektedir. Tam tersine cari işlemler dengesi, enflasyon oranı ve iç tasarruf oranlarının dış borçlar üzerinde negatif ve anlamlı bir etkiye sahip olduğu görülmektedir. Bu çalışmanın sonuçları, Orta Asya ve Kafkas ülkelerindeki dış borçlanmanın kamu harcamaları, cari işlemler açıkları ve borç servisi ödemelerinde önemli bir finansman kaynağı olarak kullanıldı ğını göstermektedir.
\end{abstract}

Anahtar Kelimeler: Dış Borçlanma, Panel Veri Analizi, Geçiş Ekonomileri, Orta Asya ve Kafkas Ekonomileri.

\footnotetext{
* The previous version of this study was presented at the Economical and International Relations IV International Congress held on 2nd-4th May 2014, Baku, Azerbaijan.

** Corresponding Author
} 


\section{Introduction}

Factors such as the insufficiency of domestic savings, the necessity of financial resources for economic development and growth, international trade and deficits in the balance of payments, and the financing of budget deficits arising from high public expenditures have made external debts an important matter. Therefore, the interest of economists and policy makers on external debts has been increased day by day. In general, the main factors affecting external debts in the literature can be listed as public revenues, public expenditures, budget deficits, loan demand, domestic debt stock, debt ceiling, debt service ratio, national income level and variability, population, social infrastructure, educational level, domestic savings, the degree of trade openness, export of goods and services, deficits in the balance of payments, imports of goods and service, current account balance, foreign exchange gap, global interest rates, capital inflow and outflow, political instability, and poverty.

The developments of the economic and political fields in the 1990s introduced states called "transition economies" transforming command economies into market economies i.e. transforming from authoritarian regimes into democratic regimes. While adopting new reforms in economic, political and socio-cultural fields, these countries have had to finance these reforms with debts. As a matter of fact, the ratio of debts to GDP exceeded a hundred percent in some of these countries and so they entered the category of countries with high debts. The financing provided by foreign debt was used in the financing of the imports of consumer goods, rather than activating economic dynamics (Uzun et al., 2012: 151). With this respect, it has been aimed at investigating the relationship between external debt levels and its affecting factors for the economies of Central Asia and the Caucasian countries of Azerbaijan, Georgia, Kazakhstan, Kyrgyzstan, Tajikistan, Turkmenistan and Uzbekistan between the years 19952017.

In the section following introduction, the causes and progress of external debt in developing countries will be briefly reviewed. Then, empirical literature on the determinants of the external debts and theoretical framework will be discussed. The next section provides econometric methodology and evaluation of the empirical findings. Finally, the last section concludes the study.

\section{The Causes and Development of External Debt in Central Asia and The Caucasus Economies}

External debt is a form of financing provided by a country, generally in foreign currency from international markets, international organizations and foreign states on the condition that they are paid back the principal amount with the interest at a set maturity date. In other words, external debt is the flow of capital from developed countries to developing countries in order to meet their needs.

One of the main problems of undeveloped and developing countries is the weakness of capital accumulation and insufficiency of domestic savings. It is an obligation for these countries to resort to external debt in order to continue economic development processes. In addition, these countries use the debt as a tool in the financing of the import of investment goods in order to carry out necessary investments (Bilginoğlu \& Aysu, 2008: 2). 
Table 1: External Debt Stocks for Developing Countries (\% of GNI)

\begin{tabular}{|c|c|c|c|c|c|c|c|}
\hline Years & $\begin{array}{c}\text { East Asia } \\
\text { and } \\
\text { Pacific } \\
\text { (developing) }\end{array}$ & $\begin{array}{l}\text { Europe and } \\
\text { Central Asia } \\
\text { (developing) }\end{array}$ & $\begin{array}{c}\text { Latin } \\
\text { America } \\
\text { and } \\
\text { Caribbean } \\
\text { (developing) }\end{array}$ & $\begin{array}{l}\text { Low } \\
\text { and } \\
\text { middle } \\
\text { income }\end{array}$ & $\begin{array}{c}\text { Low } \\
\text { income }\end{array}$ & $\begin{array}{l}\text { Lower } \\
\text { middle } \\
\text { income }\end{array}$ & $\begin{array}{l}\text { Middle East } \\
\text { and North } \\
\text { Africa } \\
\text { (developing) }\end{array}$ \\
\hline 1995 & 35.00 & 32.72 & 34.21 & 38.22 & 124.42 & 53.92 & 56.13 \\
\hline 1996 & 32.81 & 34.60 & 31.80 & 35.89 & 108.71 & 49.21 & 47.24 \\
\hline 1997 & 33.22 & 35.24 & 30.06 & 34.67 & 102.32 & 47.66 & 42.53 \\
\hline 1998 & 36.60 & 47.08 & 33.90 & 39.07 & 107.95 & 56.26 & 43.55 \\
\hline 1999 & 33.49 & 58.66 & 39.34 & 40.57 & 100.63 & 52.91 & 40.95 \\
\hline 2000 & 28.03 & 51.16 & 33.53 & 35.51 & 83.29 & 48.32 & 38.18 \\
\hline 2001 & 27.04 & 51.87 & 34.33 & 35.03 & 84.91 & 46.56 & 35.90 \\
\hline 2002 & 24.14 & 48.51 & 35.07 & 34.15 & 82.31 & 44.86 & 38.27 \\
\hline 2003 & 22.59 & 47.10 & 36.20 & 33.17 & 80.45 & 42.26 & 36.65 \\
\hline 2004 & 21.15 & 41.12 & 31.62 & 29.89 & 71.65 & 38.49 & 33.71 \\
\hline 2005 & 19.72 & 37.16 & 25.01 & 25.66 & 52.55 & 32.26 & 25.63 \\
\hline 2006 & 17.31 & 39.49 & 21.73 & 23.70 & 35.62 & 28.22 & 21.19 \\
\hline 2007 & 15.15 & 40.79 & 21.29 & 22.95 & 32.90 & 26.64 & 18.62 \\
\hline 2008 & 12.31 & 36.32 & 19.52 & 20.53 & 28.28 & 26.12 & 16.78 \\
\hline 2009 & 13.09 & 47.07 & 22.02 & 22.54 & 29.22 & 28.21 & 18.11 \\
\hline 2010 & 15.60 & 41.84 & 21.38 & 21.94 & 25.71 & 24.98 & 16.59 \\
\hline 2011 & 16.66 & 38.30 & 21.83 & 21.83 & 24.17 & 24.53 & 14.39 \\
\hline 2012 & 16.50 & 38.79 & 24.63 & 22.63 & 23.77 & 26.12 & 14.22 \\
\hline 2013 & 18.17 & 40.70 & 26.62 & 24.31 & 25.04 & 27.26 & 17.17 \\
\hline 2014 & 19.55 & 40.17 & 28.69 & 24.84 & 24.98 & 27.32 & 17.40 \\
\hline 2015 & 15.48 & 48.22 & 34.70 & 24.21 & 27.24 & 28.71 & 19.61 \\
\hline 2016 & 16.00 & 53.16 & 35.90 & 25.01 & 28.85 & 28.47 & 21.44 \\
\hline 2017 & 17.15 & 48.72 & 33.26 & 25.02 & 29.51 & 29.29 & 25.24 \\
\hline
\end{tabular}

Source: World Bank, 2018.

Data related to the change in the external debt burdens are presented in the table above by considering the categorizations carried out by the World Bank. It appears that Europe and the Central Asia, which also contain the Middle-Eastern and Caucasian countries have the highest level of external debts among these developing economies. External debt levels of these countries showed a tendency to continuously increase in the period between 1995 and 2017. In the post-2000 period, external debt burdens were valued at over 50\%. The third block with the highest debt level is composed of countries in the developing Latin American and Caribbean regions. In contradistinction to the developing European and Middle Eastern countries, the 
external debt level of these countries shows a tendency to decrease. While the average external debt burden was 36\% in the 1990s, it was at the rate of $33 \%$ in 2017 . The external debt burden also showed a tendency to decrease in these countries. In general, when the low-income, lowermiddle income and total low and middle income country categorizations are examined, external debt burdens which were over $50 \%$ in the 1990s decreased to a level between $20-30 \%$.

Table 2: External Debt Stocks for Central Asia and the Caucasus Economies (\% of GNI)

\begin{tabular}{|c|c|c|c|c|c|c|c|}
\hline$\stackrel{\mathscr{E}}{\grave{E}}$ & 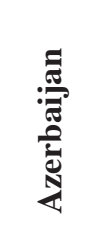 & 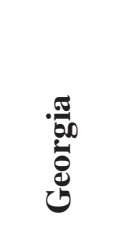 & 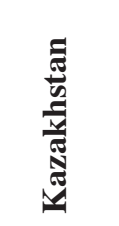 & 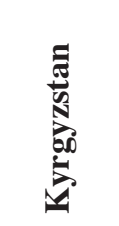 & 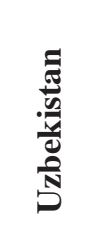 & 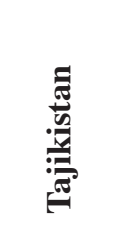 & 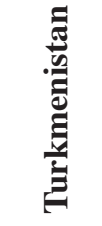 \\
\hline 1995 & 10.56 & 48.18 & 18.54 & 37.49 & 13.53 & 53.24 & 16.09 \\
\hline 1996 & 14.07 & 45.02 & 14.04 & 63.58 & 17.22 & 71.76 & 31.56 \\
\hline 1997 & 12.85 & 40.29 & 18.66 & 78.73 & 20.11 & 116.93 & 73.63 \\
\hline 1998 & 15.94 & 43.31 & 27.83 & 96.06 & 22.65 & 95.48 & 90.87 \\
\hline 1999 & 28.42 & 62.85 & 40.49 & 157.62 & 31.40 & 129.94 & 111.75 \\
\hline 2000 & 31.78 & 57.50 & 75.66 & 150.49 & 36.54 & 138.36 & 96.32 \\
\hline 2001 & 28.21 & 58.72 & 73.34 & 124.41 & 46.55 & 112.81 & 65.35 \\
\hline 2002 & 28.91 & 59.71 & 78.43 & 126.47 & 53.87 & 107.73 & 49.10 \\
\hline 2003 & 28.40 & 53.65 & 79.85 & 115.69 & 53.15 & 86.92 & 32.49 \\
\hline 2004 & 27.18 & 44.51 & 82.49 & 121.37 & 43.44 & 58.35 & 26.98 \\
\hline 2005 & 19.37 & 33.23 & 84.74 & 95.13 & 32.43 & 50.34 & 15.29 \\
\hline 2006 & 15.29 & 32.54 & 104.02 & 93.19 & 26.18 & 39.29 & 9.93 \\
\hline 2007 & 13.96 & 29.26 & 104.72 & 76.75 & 20.03 & 37.11 & 6.92 \\
\hline 2008 & 10.26 & 61.17 & 93.53 & 73.54 & 16.21 & 48.88 & 4.05 \\
\hline 2009 & 11.11 & 81.44 & 106.86 & 91.35 & 20.32 & 54.32 & 3.54 \\
\hline 2010 & 14.63 & 77.94 & 92.59 & 91.74 & 19.25 & 51.09 & 2.56 \\
\hline 2011 & 12.63 & 77.20 & 75.39 & 99.18 & 17.39 & 47.16 & 1.72 \\
\hline 2012 & 16.61 & 77.23 & 75.34 & 93.79 & 16.85 & 47.37 & 1.58 \\
\hline 2013 & 15.18 & 82.75 & 70.79 & 98.60 & 17.54 & 43.27 & 1.42 \\
\hline 2014 & 16.90 & 83.49 & 79.33 & 101.77 & 20.14 & 45.39 & 1.04 \\
\hline 2015 & 26.95 & 105.62 & 88.49 & 117.58 & 21.65 & 55.53 & 1.20 \\
\hline 2016 & 42.45 & 115.77 & 131.66 & 122.80 & 23.83 & 64.93 & 1.44 \\
\hline 2017 & 39.12 & 109.83 & 118.38 & 111.17 & 34.99 & 71.34 & 1.92 \\
\hline
\end{tabular}

Source: World Bank, 2018 
According to the Table 2, Kyrgyzstan and Kazakhstan have the highest levels of external debt burden. The general development progress of external debt burdens in Middle-Eastern and Caucasian economies shows that the external debt burden increased in periods when the structural transformation was dense and that, the external debt burden decreased in the post2000 period. The time-related transformation effect of the external debt burden also indicates the development in the form of an "Inverse -U- Curve". According to 2017 data, economies with the highest level of debts are Kazakhstan (118.38\%), Kyrgyzstan (111.17\%), Georgia $(109.83 \%)$ and, Tajikistan $(71.34 \%)$. Economies with the lowest level of debts, on the other hand, are Turkmenistan (1.92\%), Azerbaijan (39.12\%) and Uzbekistan (34.99\%). The positive transformation of the debt structure in Central Asian and Caucasian economies is an indicator that the countries moved away from economic problems arising from debts and that there were improvements in eliminating financial fragilities.

The public external debt of the Republic of Azerbaijan was 4.8126 billion dollars on January 1st, 2012. When the providers of signed loan contracts are analyzed, the shares are as follows: World Bank 29\%, Japan International Cooperation Agency 14\%, European Bank of Reconstruction and Development 12\%, Asian Development Bank 10\% and Islamic Development Bank 7\%. The share of the International Monetary Fund which is one of the two main organizations from which Azerbaijan took on debts until 2004 is 5\%. When the fact that the Azerbaijan government stopped receiving loans from this organization is taken into account, it is expected for this share to get even lower in the years to come (Bulut and Süleymanov, 2013: 280). 11.2\% was used for economic reforms of the Republic of Azerbaijan and $88.8 \%$ was used for financing investment projects (electrical energy, infrastructure, chemistry, petroleum, natural gas and the restoration of regions freed from invasion etc.) (Bulut and Süleymanov, 2013: 281).

\section{Theoretical Framework and Literature Review}

The rationale for the accumulation of external debt firstly developed by Harrod (1939) \& Domar (1946) as "Two Gap" model. This model advanced by Chenery \& Strout (1996) and explains that external debt is a path that bridges the gap between domestic savings and investments (Sa'ad et al., 2017). "Two Gap" model explains the interaction between domestic savings level and foreign exchange amount. The lack of domestic savings and foreign exchange resources pressures the countries to acquire foreign capital. In general, the reasons why countries resort to external debt can be named as follows (Açba, 1991: 6-7; Adiyaman, 2006: 22-23; İnce, 2001: 148-149; Meriç, 2013: 80; Yaşa, 1978: 30-32):

- Continuous budget deficits,

- Insufficiency of domestic savings and capital accumulation,

- High defense expenditures,

- Deficits in balance of payments,

- To provide financing for matured liabilities,

- Insufficiency of financing in industrialization and development efforts,

- Financing of expenditures in extraordinary periods (war, natural disasters, economic depressions etc.), 
- Increasing demand for imported inputs by external dependence, as a result of industrialization policies,

- Financing large infrastructure investments and reforms,

- Undeveloped financial markets and institutions.

Depending on the factors affecting external debt for developing countries, there are different perspectives in the literature. The main factor for developing countries is the insufficiency of domestic savings and capital accumulation. Especially the insufficiency of domestic savings leads countries to find external sources. In the long run, this situation causes countries to pay their debts again with new borrowings. Paying the debts with new borrowings (refinancing debts) will also cause the debt rollover ratios in the external debt policies to increase and negative developments in the debt management. Economic growth, institutions, financial markets, infrastructure investments, financing of industrialization related to economic growth are also the main determinants of external debt. Basically, many theories have emerged, especially on the basis of economic thoughts. External debt has become even more important with The Keynesian view. These theories generally focus on economic growth and efficiency through borrowing. With this respect, the empirical studies analyzing the relationship among external debt and other economic variables will be discussed in this section of the study. The study conducted by Eaton \& Gersovitz (1981) is one of the first studies in the literature, analyzing the factors which determine the external debts with data of 81 developing countries for the 1970-1974 period. They created a theoretical model in their study and according to the empirical results of this model, the main factors determining the debt of a country are loan demand and debt ceiling of these countries. They found a positive relationship between loan demand and income variability, the variability of exports, and income level. Eichengreen \& Portes (1986) analyzed the relationship among central government external debt level and gross domestic product per capita, population, the degree of openness, and export instability for 23 countries over the period 1930-1938. Their empirical findings showed that economic growth has positive effect on external debts, while export instability and external openness have a statistically insignificant negative effect on the external debts.

Hajivassiliou (1987) examined the variables of debt service to export ratio, the reserves to imports ratio, real GDP per capita, and the rate of export to GDP as the dynamics determining the external debt demand, using data for 79 developing countries over the period 1970-1982. The results show that factors other than economic growth increase the external debt demand. Ozler \& Tabellini (1991) found positive relationship between political instability and external debts for 55 countries in the period of 1970-1999. As a result of the study, they stated that the external debt would be higher in countries with higher political instability.

Karagöl (2002) examined the relationship between external debt and economic growth for Turkey using annual data for the period 1956 and 1996. The results show unidirectional negative causal relationship between debt service and GNP level. Edo (2002) examined the effects of public expenditures, the balance of payments and global interest rates on the external debts for Morocco and Nigeria covering periods between 1980 and 1999. The findings show that the balance of payments and domestic saving rates negatively affect the external debts, on the contrary, global interest rates and public expenditures positively affect the external debts. It was determined in the study conducted by Tiruneh (2004) with the panel data analysis method 
for the period of 1982-1998 that poverty, income variability, debt service, capital flight, and foreign exchange gap were the main determinants of the external debts. Lane (2004), with the panel data analysis method, studied the external debt and its determinants for 55 developing countries in the period of 1970-1998. The research findings show that GDP per capita, the rate of export to GDP, social infrastructure, and education have a positive effect on external debts.

Karagöl (2005) investigated the causal relationship between defence expenditures and external debt in Turkey over the period 1955-2000. The findings show that there is a causality from defence expenditures to external debt. Karagöz (2007) studied the causes of external debt in Turkey with data covering the period between 1980 and 2004. The research findings show that domestic savings and internal debts negatively affect the external debts but that deficits in the balance of payments positively affect the external debts. Colombo \& Longoni (2009) investigated the determinants of external debts for developing countries. In addition to the economic variables, they found positive relationship between institutional quality, competitive electoral system and external debts.

Oatley (2010), by using the error correction model, determined in his study of 78 developing countries covering the period between 1976 and 1998 that autocratic governments were more inclined to go into debt than democratic governments. Loganathan et al. (2010) analyzed the relationship between external debts and macro-economic performance in Malaysia for the period of 1988-2008 using the time series analysis method. They showed that there was a relationship among external debts and budget incomes, the balance of payments and reserves in the long and short term but that there was no relationship of causality among them. Koyuncu \& Tekeli (2010) investigated the effect of current account deficits, domestic savings, internal debt ratio and public expenditures on external debts in Turkey during the period 1990-2009. The research findings show that the level of domestic savings and current account deficit have a significant effect on external debts.

Awan et al. (2011) tested the relationship between the external debts, foreign exchange rate, foreign trade and budget deficit in Pakistan considering the 1974-2008 period. The decrease in the foreign exchange rate and deterioration of foreign trade in Pakistan were determined as the main reasons for the external debts. Together with this, they showed that budget deficits and external debts were related to each other in the long term. Uzun et al. (2012) analyzed the causality relationship between external debts and economic growth for seven Central Asian and Caucasian economies over the period 1993-2009. According to the empirical results, it was determined that economic growth has a significant effect on long-term external debts as well as affecting the total external debt stock, and that the current account deficit was one of the main causes of external debts in the countries included in the analysis.

Peker \& Bölükbaş (2013) analyzed the determinants of the external debts in Turkey using quarterly data from 1994 through 2010 and 2001 through 2010. When the 1994-2010 period is considered, it was determined that public expenditures, domestic debt have a positive effect on external debts. On the other hand, when the 2001-2010 period is considered, it is seen that public expenditures have a positive effect on external debts while the balance of payments has negative effect on external debts.

Imimole et al. (2014) found that the main determinants of Nigeria's external debt are debt service, gross domestic product, and exchange rate. Lau et al. (2015) found short run 
causality relationship between the macroeconomic indicators and the external debt and in Malaysia covering the period between 1970 and 2013. Abdullahi et al. (2015) examined the macroeconomic factors of external debt accumulation in Nigeria for the 1980 to 2013 period. The empirical results show that interest rate, exchange rate, and budget deficits have negative effect on external debt in the long and short term. Yamaçli (2015) investigated the determinants of foreign debt in Turkey. It has been concluded that real exchange rate, noninterest public debt requirement, domestic interest rate and the economic growth rate are the main factors affecting the external debt. Awan et al. (2015) examined macroeconomic determinants of external debt in Pakistan for the period of 1976-2010. Their findings indicate that trade openness and nominal exchange rate are statistically significant determinants of external debt.

Lau \& Lee (2016) used time series for Thailand and the Philippines for 1976- 2013. Their results imply that the existence of short-run linkages originated from inflation rate, real interest rate to external debt. Al-Fawwaz (2016)'study for Jordan during the period 1990-2014 reveals that there is a positive effect of trade on the external debt, and a negative effect of economic growth on the external debt in the long run.

Waheed (2017) examined the macroeconomic determinants of external debt for 12 oil and gas exporting countries and 12 oil and importing countries for the period 2004- 2013. The results show that increased economic growth, general government revenue, foreign exchange reserves, price of oil, and domestic investment are the important factors in reducing external debt. Akduğan (2017) analyzed the determinants of external debt in Turkey for the period of 1970-2015 by using ARDL bound test approach. It is concluded that there is a significant negative relationship between inflation rate, exchange rate regime, money supply, and external debt. On the contrary, it is determined that the effect of GDP per capita, debt service, budget balance, domestic credits and trade openness on external debt stock are statistically significant and positive. Saad et al. (2017) also investigated the determinants of external debt using ARDL Cointegration Technique in Nigeria from 1973 - 2013. Findings from the study show that inflation rate, interest rate, economic growth, and money supply are cointegrated with external debt in both the short-run and long-run. Özata (2017) investigated the impact of interest rates, savings, exchange rates and budget deficits on external debt in Turkey and concluded that those variables have significant effect on the accumulation of external debt both in the short and the long run.

Nguyen (2018) examined the relationship between external debt, economic growth, unemployment and national expenditure for Vietnam over the period of 1987-2016. The results of this study show that there are directional relationships between unemployment and external debt, GDP, and national expenditure. Bittencourt (2018) investigated the main determinants of government and external debt in the young democracies of South America between 1970 and 2007. The results based on dynamic panel time-series analysis show that economic growth has a significantly negative effect on external debt. Kamac1 (2018) investigated the determinants of foreign debts using annual data between the periods of 1975-2017 for Turkey. The results show that economic growth, inflation and budget deficits have statistically positive effect on external debt. Chiminya et al. (2018) investigated the factors affecting external debt for 36 Sub Saharan Africa Countries over the period 1975 to 2012. They considered the effect of sociopolitical factors as well as the usual macroeconomic ones and they found that parliamentary systems 
seemed to accumulate more debt than presidential democracies. Moreover, they determined that countries with more open and competitive electoral systems tend to lead to the accumulation of less debt.

Toktaş et al. (2019) examined the relationship between Turkey's foreign debt and economic growth using annual data for the period of 2003Q and 2017Q. The empirical results of this study show that there is a causality relationship between net foreign debt stock and economic growth. Arslan \& Athwari (2019), examined the factors affecting the external debt for Turkey for the period of 1980-2017. The empirical results show that showed that economic growth, foreign direct investment, foreign reserves and debt service to exports are the most important factors affecting the external debt.

In empirical studies conducted in the literature, the factors determining the external debt for developing countries were taken as economic growth, domestic savings, the variability of exports and imports, the degree of openness, debt service, public expenditures, public revenues, the balance of payments, foreign exchange rate, population, social infrastructure, educational level, current account balance, etc. This study investigates the factors affecting external debt for Central Asian and Caucasian countries. In this respect, this study differs from other studies in the literature. In the empirical part of the study, factors determining external debt were estimated in accordance with previous studies in the literature. With this aim, explanatory variables are taken economic growth, public expenditures, the average rate of inflation, deficits in the balance of payments, domestic saving rate, and debt service.

\section{Data and Model Specifications}

In this section, the factors affecting external debt in Central Asian and Caucasian countries will be analyzed. The analysis covers the years between 1995 and 2017 for the countries of Azerbaijan, Georgia, Kazakhstan, Kyrgyzstan, Tajikistan, Turkmenistan and Uzbekistan. Although it is seen that many variables have effects on the external debts in the literature, the current model in this study is estimated by taking the data limitation, significance and theoretical framework into account. The datasets are obtained from World Development Indicators (WDI) and the International Monetary Fund (IMF). In the study, while the dependent variable is taken as external debt stock (EXDEBT), explanatory variables are economic growth (GDPGR), public expenditures (PEXP), the average rate of inflation (INF), deficits in the balance of payments (BOP), domestic saving rate (DSAV) and debt service (DSERV). All variables are taken as a share of GDP (constant 2010, USD). Stata 12 and Gauss 10 statistical packages are used in the econometric analysis. Table 3 provides descriptive statistics for the variables in the study. 
Table 3: Descriptive Statistics

\begin{tabular}{lccccccc}
\hline & EXDEBT & GDPGR & PEXP & BOP & DSAV & DSERV & INF \\
\hline Mean & 0.392729 & 4.871827 & 0.264811 & -0.017151 & 0.159612 & 0.047678 & 433.0675 \\
\hline Median & 0.262543 & 4.762642 & 0.252990 & -0.016502 & 0.098084 & 0.030477 & 153.8205 \\
\hline Maximum & 1.249420 & 33.03049 & 0.440360 & 0.356812 & 0.937807 & 0.266628 & 4297.232 \\
\hline Minumum & 0.010814 & -17.90799 & 0.108660 & -0.247428 & -0.207005 & 0.000000 & 4.461000 \\
\hline Std. Dev. & 0.322976 & 5.946947 & 0.079144 & 0.095451 & 0.213474 & 0.051484 & 740.2199 \\
\hline Skewness & 0.928594 & 0.166385 & 0.296568 & 1.175912 & 1.283857 & 1.909832 & 3.136295 \\
\hline Kurtosis & 2.890680 & 8.384185 & 2.040408 & 5.965525 & 4.87808 & 6.555517 & 13.29725 \\
\hline Jarque-Bera & 23.21821 & 195.2138 & 8.537208 & 96.09964 & 65.78222 & 182.6782 & 444.9623 \\
\hline Obs. & 161 & 161 & 161 & 161 & 156 & 161 & 161 \\
\hline
\end{tabular}

Table 4 shows the variance inflation factor (VIF), tolerance coefficients and correlation values among the variables. Table 4 indicates that there is no multicollinearity between all independent variables.

Table 4: Correlation Matrix of the Variables

\begin{tabular}{|c|c|c|c|c|c|c|c|c|c|}
\hline & EXDEBT & GDPGR & PEXP & BOP & DSAV & DSERV & INF & VIF & Tolerance \\
\hline EXDEBT & 1 & & & & & & & & \\
\hline GDPGR & -0.1548 & 1 & & & & & & 1.07 & 0.93 \\
\hline PEXP & 0.3140 & -0.2003 & 1 & & & & & 1.08 & 0.92 \\
\hline BOP & -0.3804 & 0.0899 & 0.0364 & 1 & & & & 1.53 & 0.65 \\
\hline DSAV & -0.3268 & 0.1481 & 0.1119 & 0.5431 & 1 & & & 1.53 & 0.65 \\
\hline DSERV & 0.7203 & -0.0803 & 0.0925 & -0.1606 & 0.0633 & 1 & & 1.09 & 0.92 \\
\hline INF & -0.1070 & 0.0478 & 0.2718 & 0.1289 & 0.1607 & -0.0944 & 1 & 1.10 & 0.90 \\
\hline
\end{tabular}

The panel data method is used to analyze external debts and causal factors (GDPGR, PEXP, INF, BOP, DSAV, and DSERV) for Central Asian and Caucasian countries. The direction and size of the relationship among the external debts between 1995 and 2017 and the factors affecting the external debts are determined in the study within the context of said methods and data. The definitions of the data used in the study are summarized in Table 5 . 
Table 5: Variables, Descriptions and Measures

\begin{tabular}{lllc}
\hline & \multicolumn{1}{c}{ Variable } & Source & Expected Impact \\
\hline EXDEBT & External Debt (\%GDP) & WDI, IMF & \\
\hline GDPGR & Growth Rate of Gross Domestic Product (\%) & WDI, IMF & $-/+$ \\
\hline PEXP & Public Expenditures (\% GDP) & WDI, IMF & + \\
\hline INF & The average of Inflation rate $(\%)$ & WDI, IMF & $-/+$ \\
\hline BOP & Balance of Payments (\% GDP) & WDI, IMF & - \\
\hline DSAV & Domestic Savings (\% GDP) & WDI, IMF & $-/+$ \\
\hline DSERV & Debt Service Ratio (\% GDP) & WDI, IMF & + \\
\hline
\end{tabular}

Four separate model were generated to overcome the endogeneity problem for all models. External debt to GDP (EXDEBT) is used as the dependent variable in all of these models, and growth rate of gross domestic product (GDPGR), the average of inflation rate (INF) and public expenditures (PEXP) are added to main models as macroeconomic control variables. Model 1 was created to analyze the levels of significance of the macro variables used. Model 2, 3 and 4 were set up to examine the direction of the relationship between external debt and balance of payments (BOP), domestic saving rate (DSAV) and debt service ratio (DSERV).

Model 1: $E X D E B T_{i t}=\beta_{0}+\beta_{1} G D P G R_{i t}+\beta_{2} P E X P_{i t}+\beta_{3} I N F_{i t}+e_{i t}$

Model 2: $E X D E B T_{i t}=\beta_{0}+\beta_{1} G D P G R_{i t}+\beta_{2} P E X P_{i t}+\beta_{3} I N F_{i t}+\beta_{4} B O P_{i t}+e_{i t}$

Model 3: $E X D E B T_{i t}=\beta_{0}+\beta_{1} G D P G R_{i t}+\beta_{2} P E X P_{i t}+\beta_{3} I N F_{i t}+\beta_{4} D S A V_{i t}+e_{i t}$

Model 4: $\operatorname{EXDEBT}_{i t}=\beta_{0}+\beta_{1} G D P G R_{i t}+\beta_{2} P E X P_{i t}+\beta_{3} I N F_{i t}+\beta_{4} D S E R V_{i t}+e_{i t}$

\section{Empirical Analysis and Findings}

Similar to the time series analysis, the variables in the panel data analysis also need to be stationary. The fact that panel data has the time aspect along with the unit aspect puts forward the necessity of researching the stationarity of the series with the aim of determining the process which creates the data (Şak, 2015: 203). Conducting the analysis with non-stationary process may lead to problems associated with risk of spurious regression (Tatoğlu, 2013: 199). Unit root tests are mainly categorized into two groups according to whether there is correlation among units (cross-section dependence) (Şak, 2015: 204; Tatoğlu, 2013: 199). The tests developed for situations where there is no cross-sectional dependency are named as first generation panel unit root tests, while the tests used where cross-sectional dependency exists, are named as second generation panel unit root tests (Şak, 2015: 204; Tatoğlu, 2013: 199). The Levin, Lin \& Chu (2002) test, Harris \& Tzavalis (1999) test, Breitung (2000) test, Fisher ADF test (Maddala \& Wu, 1999), Fisher Philips \& Peron test (Choi, 2001), Hadri (2000) test and Im, Pesaran \& Shin (2003) test can be counted among the frequently used first generation panel unit root tests in the literature (Şak, 2015: 204; Tatoğlu, 2013: 199). 
The Pesaran (2004) test, Bai \& NG (2004) test, Phillips \& Sul (2003) test, Moon \& Perron (2004) test, Choi (2002) test and Chang (2002) test can be counted as second generation panel unit root tests developed by assuming that there is a cross-sectional dependency among the series belonging to the units (Şak, 2015: 222; Tatoğlu, 2013: 220). Before determining the stationarity of the series (variables) in panel data analyses, their cross-section dependence needs to be tested. If there is no cross-section dependence in the used variables, first generation panel unit root tests can be used. Second generation panel unit root tests are used with crosssection dependence. Although it is assumed that all cross-section units are affected at the same level by the shocks reaching the units in the panel data analyses and that macro-economic shocks do not affect each other, the possibility that a unit would be affected at a different level by a shock reaching one of the cross-section units which form the panel can be said to be more realistic, when the economies of our day are taken into consideration (Mercan, 2014: 235). The selected method considering this fact will yield more consistent and efficient results in the tests used in the estimations and analysis. Therefore, before determining the stationarity level of the variables, their cross-section dependence will be tested.

Cross-section dependency is tested with Breusch \& Pagan (1980) CDLM1 test, Pesaran (2004) CDLM2 test, Pesaran (2004) CDLM test and Pesaran, Ullah \& Yamagata (2008) CDLMadj test. Breusch \& Pagan (1980) CDLM1 test is used when N is constant and T $\rightarrow \infty$. It can be said that this test will not be suitable for large cross-section observations and is used when $\mathrm{N}$ is large relative to $\mathrm{T}(\mathrm{T}>\mathrm{N})$. Pesaran (2004) CDLM tests the cross section dependence when $\mathrm{N}>\mathrm{T}$. Pesaran (2004) CDLM2 is used when $\mathrm{N}$ and $\mathrm{T}$ are great $(\mathrm{T} \rightarrow \infty$ and $\mathrm{N} \rightarrow \infty)$. However, Pesaran (2004) pointed out that this test may not be suitable when $\mathrm{N}>\mathrm{T}$ (Guloglu \& Ivrendi, 2010:384). Therefore, Pesaran (2004) CDLM2 test is more consistent and efficient when T $>$ N. The Pesaran, Ullah \& Yamagata (2008) CDLMadj (Bias-Adjusted Cross-sectional Dependence Lagrange Multiplier) test is more consistent and efficient in both cases $(\mathrm{T}>\mathrm{N}$, $\mathrm{N}>\mathrm{T}$ ).

Table 6: Cross Section Dependence Test Results of the Variables

\begin{tabular}{|c|c|c|c|c|}
\hline & $\begin{array}{c}\text { CDLM } \\
\text { Pesaran } \\
(2004) \\
\text { t-stat p-value } \\
\end{array}$ & $\begin{array}{c}\text { CDLM }_{1} \\
\text { Breusch-Pagan } \\
(1980) \\
\text { t-stat p-value } \\
\end{array}$ & $\begin{array}{c}\text { CDLM }_{2} \\
\text { Pesaran } \\
(2004) \\
\text { t-stat p-value } \\
\end{array}$ & $\begin{array}{c}\text { CDLM }_{\text {adj }} \\
\text { Pesaran et al. } \\
(2008) \\
\text { t-stat p-value }\end{array}$ \\
\hline EXDEBT & $-8.895(0185)$ & $35.943(0.022)$ & $2.306(0.011)$ & $5.849(0.000)$ \\
\hline GDPGR & $-2.162(0.015)$ & $34.336(0.033)$ & $2.058(0.020)$ & $-0.697(0.757)$ \\
\hline PEXP & $-2.812(0.002)$ & $36.472(0.019)$ & $2.387(0.008)$ & $-0.605(0.727)$ \\
\hline INF & $21.47(0.000)$ & $461.231(0.000)$ & $66.689(0.000)$ & $66.849(0.000)$ \\
\hline BOP & $-1.611(0.054)$ & $51.565(0.000)$ & $4.716(0.000)$ & $-0.469(0.680)$ \\
\hline DSAV & $-2.316(0.478)$ & $38.950(0.010)$ & $2.770(0.003)$ & $-0.075(0.530)$ \\
\hline DSERV & $-0.054(0.002)$ & $34.787(0.030)$ & $2.127(0.017)$ & $-0.139(0.555)$ \\
\hline
\end{tabular}

The results of the cross-section dependence tests are summarized in Table 6. According to the results, it is determined that there is cross-section dependency in all series of this 
analysis, rejecting the null hypothesis. Therefore, it is concluded that the shocks reaching the countries also affect other countries for all variables. These results indicate strong evidence of cross-section dependence for all variables. Since it is determined that there is cross-section dependence, first generation panel unit root tests are not sufficient and thus the results of the second generation panel unit root tests need to be analyzed.

Pesaran (2007) developed the Cross-Sectional Augmented Dickey Fuller (CADF) test eliminating the first difference correlation among the units by using the augmented version cross-section averages of the ADF regression (Tatoğlu, 2013: 223). The Pesaran CADF panel unit root test is a second generation panel unit root test which also takes the cross-section dependence into account. Table 7 shows the results of the second generation panel unit root test of all the variables in the model. The results show that all variables are stationary in first difference.

Table 7: Results of Second Generation Pesaran CADF Unit Root Test*

\begin{tabular}{lccc}
\hline & t-bar & Z[t-bar $]$ & $\mathbf{p}$ \\
\hline EXDEBT & -3.215 & -3.967 & 0.000 \\
\hline GDPGR & -4.647 & -7.875 & 0.000 \\
\hline PEXP & -3.025 & -3.450 & 0.000 \\
\hline INF & -2.880 & -3.056 & 0.000 \\
\hline BOP & -3.995 & -6.097 & 0.000 \\
\hline DSAV & - & -2.860 & 0.002 \\
\hline DSERV & -2.637 & -2.392 & 0.000 \\
\hline
\end{tabular}

*Values show Cross-Sectionally Augmented IPS (CIPS) statistics, which are average of CADF.

The regression models estimating the external debts and their causal factors (GDPGR, PEXP, BOP, DSAV, and DSERV) for the Central Asian and Caucasian countries studied were reported according to the ordinary least squares method (OLS) using fixed effect model, random effect model and pooled model, depending on the existence of regional effects. Whether the random effect model or pooled model is suitable can be tested with the Breusch and Pagan Lagrange Multiplier (LM) test. According to the results of all models, the rejection of the null hypothesis points out that the pooled OLS would not be suitable in all models and shows that there is existence of individual effects (panel effect) against the random effects. After determining the all models used in our study has individual effects, it should be decided whether these effects are fixed or random. For this reason, the Hausman (1978) Specification test was developed in order to determine the fixed or random effects among the estimators. Hausman tests the null hypothesis that "the difference in coefficients is not systematic (random effect is suitable)" (Tatoğlu, 2012: 183). The rejection of the null hypothesis means that random effects are not suitable, and the estimator of fixed effects is appropriate. Hausman test results of all models show that fixed effects specification is appropriate in our models. In order to estimate the models created in the study, the fixed effects will be taken into account. Pooled, random and fixed effect models in the panel data analysis are based on the assumptions that there is no 
presence of cross-section dependence, autocorrelation and heteroskedasticity. If one or several assumptions are not provided, this causes loss of efficiency in the estimated parameters and the misestimating of standard errors (Ün, 2015: 71). The problems of autocorrelation, cross-section dependence and heteroskedasticity in the random effect model selected for this study will be tested and the most suitable estimation method will be selected according to the results.

The existence of cross-section dependence in the created models besides the crosssection dependence of the series in the panel data analysis affects the parameters in the same way as it affects the effectiveness of the estimated model and the consistency. The cross-section dependence in the fixed effect model to be used in the study is tested with Pesaran CDLM test (2004), Friedman R test (1937) and Frees Q test. According to the results of related tests, there exist cross-section dependence for all models. Heteroskedasticity in the fixed effect model is one of the basic assumptions which arises from changing the variance of one or both of the error components for the panel units (Ün, 2015: 72). The heteroskedasticity in all models was tested with Lagrange Multiplier Test (LM) and Modified Wald test. These tests reveal that heteroskedasticity appears in all models. One of the most fundamental assumptions in the models evaluated in the panel data analysis is the fact that there is an autocorrelation between error terms. Making estimations by ignoring the autocorrelation causes the parameters to be consistent but not efficient which causes standard errors bias (Tatoğlu, 2012: 225). To examine the autocorrelation, the Wooldridge test was used in all models. The results of Wooldridge test for all estimations indicate the presence of serial correlation. The assumption tests conducted in the analysis for all models have heteroscedasticity, cross-section dependence and serial correlation problems. With this respect, the 'panel-corrected standard errors' (PCSE) estimator was used to estimate the models which robust to heteroscedasticity and cross-sectional dependence and serial correlation.

Table 8: Prais-Winsten (PCSE) Panel Regression Models

\begin{tabular}{lcccc}
\hline Dependent Variable: EXDEBT & & & \\
Variables & $\begin{array}{c}\text { Prais-Winsten } \\
\text { (PCSE) } \\
\text { (Model 1) }\end{array}$ & $\begin{array}{c}\text { Prais-Winsten } \\
\text { (PCSE) } \\
\text { (Model 2) }\end{array}$ & $\begin{array}{c}\text { Prais-Winsten } \\
\text { (PCSE) } \\
\text { (Model 3) }\end{array}$ & $\begin{array}{c}\text { Prais-Winsten } \\
\text { (PCSE) } \\
\text { (Model 4) }\end{array}$ \\
\hline \multirow{2}{*}{ GDPGR } & -0.0038 & -0.0021 & -0.0024 & -0.0020 \\
& $(-1.06)$ & $(-0.62)$ & $(-0.64)$ & $(-0.91)$ \\
\hline \multirow{2}{*}{ PEXP } & 1.5753 & 1.6697 & 1.2949 & 1.1593 \\
& $(8.12)^{* * *}$ & $(7.69)^{* * *}$ & $(7.69)^{* * *}$ & $(5.81)^{* * *}$ \\
INF & -0.000 & -0.000 & -0.000 & -0.000 \\
& $(-3.02)^{* * *}$ & $(-2.76)^{* *}$ & $(-2.62)^{* *}$ & $(-2.39)^{*}$ \\
\hline \multirow{2}{*}{ BOP } & & -1.1180 & & \\
\hline \multirow{2}{*}{ DSAV } & $(-4.40)^{* * *}$ & & \\
\hline
\end{tabular}


Table 8 continued

\begin{tabular}{lcccc}
\hline DSERV & & & & 4.2639 \\
& & & & $(16.18)^{* * * *}$ \\
\hline $\mathrm{R}^{2}$ & 0.1654 & 0.2717 & 0.2075 & 0.6114 \\
\hline Wald Chi2 & 72.32 & 62.82 & 153.19 & 346.39 \\
(Prob.) & $(0.000)$ & $(0.000)$ & $(0.000)$ & $(0.000)$ \\
\hline Obs. & 161 & 161 & 156 & 161 \\
\hline
\end{tabular}

Notes: The t-statistics are in parentheses. ${ }^{* * *},{ }^{* *},{ }^{*}$ represent $\% 1, \% 5$ and $\% 10$ significant level respectively. The data sample includes yearly observation for the Central Asia and the Caucasus Economies over the period 1995-2017.

The results of Prais-Winsten Regression Estimation (PCSE) are reported in Table 8. The results show that there is a negative relationship between economic growth and external debt, but this result is not statistically significant. It is determined that the estimated coefficient of the public expenditures (PEXP) has a statistically and significantly positive impact on external debt while inflation rate has a negative impact on external debt in all the estimated models. Negative and statistically significant effect of balance of payment (BOP) found in Model 2, which is one of the important financing sources of the external debt. It can be stated that current account balance is among the basic dynamics for the external debt in the sustainability process of current deficit for these countries. The impact of the debt service (DSERV) on the external debt is statistically significant and positive at the $1 \%$ significance level in Model 4. External debt level has a positive effect in meeting the debt service (total of principal amount and interest payments) in the borrowing policies for Central Asian and Caucasian countries. Paying the debts with new borrowings (refinancing debts) will cause the debt rollover ratios in the external debt policies to increase and will cause negative developments in the debt management. Moreover, it is determined that there is a negative and significant relationship between domestic saving rate (DSAV) and external debt in Model 3. Therefore, when the relevant period and data set are considered, the domestic saving rate negatively affects the external debt for Central Asian and Caucasian countries. For the period under analysis, it can be stated that the change in the public expenditures and debt service ratio caused a positive and statistically significant effect on external debt, on the contrary, current account balance and domestic saving rates affect external debt in the negative direction. In addition to this, it is concluded that economic growth negatively affected the external debt but is statistically insignificant.

\section{Conclusion}

The factors affecting the external debt for developing countries in the literature include deficits in balance of external payments, problems arising from the insufficiency of domestic savings, high public expenditures and budget deficits, economic growth, financing development, debt stocks and increases in the debt burden. In this study, the factors affecting the external debt are analyzed for Central Asian and Caucasian countries over the period 19952017. First, the existence of cross-sectional dependence among the variables is investigated and the Cross-Sectional Augmented Dickey-Fuller Test (CADF) developed by Pesaran (2006), which considers the cross-sectional dependency, is used to investigate the stationarity of 
variables. In addition to this, the relationship among external debt and the factors affecting external debt are estimated by using the panel regression method. It is determined, as a result of the panel unit root test, that variables are stationary in first difference. Panel regression results show that public expenditures and debt service positively affect external debt. On the contrary, current account balance and domestic saving rates negatively affect external debt. It is concluded that economic growth affected the external debt but is statistically insignificant. These results consistent with the empirical findings of Edo (2002), Karagöz (2007), Koyuncu \& Tekeli (2010), Uzun et. al. (2012) and Peker \& Bölükbaş (2013). The results of this study show that external debt is used as an important source in financing public expenditures, current account deficits and external debt repayments in Central Asian and Caucasian countries. With this perspective, the main results of this study supports the empirical results of Uzun et. al. (2012). With these findings, this study contributes to the literature by providing an empirical analysis of the determinants of external debt in Central Asian and Caucasian countries.

In this study, the main factors empirically affecting external debt in Central Asian and Caucasian countries are determined to be public expenditures, domestic saving rate, foreign trade deficit and debt service. It can be said that public expenditures, foreign trade deficit and domestic saving level are variables that are interrelated in terms of external debt for these countries. The fact that debt service is positively related to the external debts is seen as a sign of financing the external debt payments with new debts and this caused the debt rollover ratios to increase and led to negative developments in debt management. When these results are taken into consideration, the following suggestions can be made for these countries. it is needed to prioritize policies focusing on export and foreign exchange revenues and to keep external debt credibility high in order to decrease the foreign trade deficits of the countries. Policy makers need to take measures to strengthen the balance of payments and foreign exchange reserves to prevent future problems in debt service.

\section{References}

Açba, S. (2016). Devlet borçlanması. Ankara: Adım Yayıncılık.

Adıyaman, A.T. (2006). Dış borçlarımız ve ekonomik etkileri. Sayıştay Dergisi, 62, 21-45.

Abdullahi, M. M., Abu Bakar, N.A., \& Hassan, S.B. (2015). Determining the macroeconomic factors of external debt accumulation in Nigeria: An ARDL bound test approach. 2nd Global Conference on Business and Social Sciences, September 17-18, Bali, Indonesia.

Al-Fawwaz, T.M. (2016). Determinants of external debt in Jordan: An empirical study (1990-2014). International Business Research, 9(7), 116-123.

Arslan, E., \& Athwari, B. (2019). The factors affecting the external debt: Case of Turkey. International Social Sciences Studies Journal, 5(31), 1295-1301.

Akduğan, U. (2017). Türkiye'de dış borç stokunun belirleyicileri. Business and Economics Research Journal, 8(2), 183-202.

Awan, A., Asghar, N., \& Ur Rehman, H. (2011). The impact of exchange rate, fiscal deficit and terms of trade on external debt of Pakistan. Australian Journal of Business and Management Research, 1(3), 10-24.

Awan, R.U., Anjum, A., \& Rahim, S. (2015). An econometric analysis of determinants of external debt in Pakistan. British Journal of Economics, Management \& Trade, 5(4), 382-391. 
Bai, J., \& Ng, S. (2004). A panic attack on unit roots and cointegration. Econometrica, 72(4), 1127-1177.

Bilginoğlu, M. A., \& Aysu, A. (2008). Dış borçların ekonomik büyüme üzerindeki etkisi: Türkiye örneği. Erciyes Üniversitesi İktisadi ve İdari Bilimler Fakültesi Dergisi, 31, 1-23.

Bittencourt, M. (2018). Young democracies and government debt: Evidence from South America. Journal of Economic Policy Reform,22(4), 351-368.

Breitung, J. (2000). The local power of some unit root tests for panel data. İçinde B.H. Baltagi, T.B. Fomby \& R. C. Hill (ed.), Nonstationary Panels, Panel Cointegration and Dynamic Panels (ss. 161-177). Amsterdam: Elsevier.

Breusch, T. S., \& Pagan, A. R. (1980). The lagrange multiplier test and its applications to model specification in econometrics. The Review of Economic Studies, 47(1), 239-253.

Bulut, C., \& Süleymanov, E. (2013). Dövlet maliyyesi. Bakü: Qafqaz Universiteti Nəşri.

Chang, Y. (2002). Nonlinear IV unit root tests in panels with cross-sectional dependency. Journal of Econometrics, 110(2), 261-292.

Chenery, S., \& Strout, A.M. (1966). Foreign assistance and economic development. The American Economic Review, 56(4), 679-733.

Choi, I. (2001). Unit root tests for panel data. Journal of International Money and Finance, 20(2), 249-272.

Chiminya, A., Dunne, J. P., \& Nikolaidou, E. (2018). The determinants of external debt in Sub Saharan Africa. University of Cape Town School of Economics Macroeconomic Discussion Paper Series, $2,1-20$.

Colombo, E., \& Longoni, E. (2009). The politics of external debt in developing countries. University of Milan Department of Economics Working Paper Series, 176, 1-22.

Domar, E.D. (1946). Capital expansion, rate of growth, and employment. Econometrica The Econometric Society, 14(2), 137-147.

Eaton, J., \& Gersovitz, M. (1981). Debt with potential repudiation: Theoretical and empirical analysis. The Review of Economic Studies, C. 48(2), 289-309.

Edo, S. E. (2002). The external debt problem in Africa: A comparative study of Nigeria and Morocco. African Development Review, 14(2), 221-236.

Eichengreen, B., \& Portes, R. (1986). Debt and default in the 1930s: Causes and consequences. National Bureau of Economic Research Working Paper, 1772, 1-61.

Güloğlu, B., \& İvrendi, M. (2010). Output fluctuations: Transitory or permanent? The case of Latin America. Applied Economics Letters, 17(4), 381-386.

Hadri, K. (2000). Testing for stationarity in heterogeneous panel data. The Econometrics Journal, 3(2), 148-161.

Hajivassiliou, V. A. (1987). The external debt repayments problems of LDC's: An econometric model based on panel data. Journal of Econometrics, 17(1-2), 205-230.

Harris, R. D., \& Tzavalis, E. (1999). Inference for unit roots in dynamic panels where the time dimension is fixed. Journal of Econometrics, C. 91(2), 201-226.

Harrod, R. F. (1939). An essay in dynamic theory. The Economic Journal, 49(193), 14-33.

IMF (2018). World economic outlook databases. (Erişim Tarihi: 14.10.2018, https://www.imf. org/ external/pubs/ft/weo/2018/01/weodata/index.aspx).

Im, K. S., Pesaran, M. H., \& Shin, Y. (2003). Testing for unit roots in heterogeneous panels. Journal of Econometrics, 115(1), 53-74. 
Imimole, B., Ehikioya, E. L., \& Okhuese, M. A. (2014). Determinants and sustainability of external debt in a deregulated economy: A cointegration analysis from Nigeria (1986-2010). American International Journal of Contemporary Research, 4(6), 201-214.

İnce, M. (2001). Devlet borçları ve Türkiye. Ankara: Gazi Kitabevi.

Kamaci, A. (2018). Determinants of the external depy: The case of Turkey. İçinde W. Eszter, O. Şimşek \& Ş. Apaydın (ed.), Economic \& Management Issues in Retrospect \& Prospect (ss. 145-156). London: IJOPEC Publication.

Karagöl, E. (2002). The causality analysis of external debt service and GNP: The case of Turkey. Central Bank Review I, 39-64.

Karagöl, E. (2005). Defence expenditures and external debt in Turkey. Defence and Peace Economics, $16(2), 117-125$.

Karagöz, K. (2007). Türkiye'de dış borçlanmanın nedenleri: Ekonometrik bir değerlendirme. Sayıştay Dergisi, 66-67, 99-110.

Koyuncu, F.T., \& Tekeli, S. (2010). 1990 Sonrası dönemde Türkiye'de dış borç stoku üzerinde etkili olan ekonomik faktörlerin analizi. Ekonomi Bilimler Dergisi, 2(1), 123-130.

Lane,P.R.(2004).Empirical perspectives on long-term external debt. The B.E. Journal of Macroeconomics, 4(1), 1-23.

Lau, E., Lee, A.S., \& Arip, M. A. (2015). Macroeconomics determinants of external debt in Malaysia. International Journal of Economic Sciences, 4(4), 14-26.

Lau, E., \& Lee, A.S. (2016). Determinants of external debt in Thailand and the Philippines. International Journal of Economics and Financial Issues, 6(4), 1973-1980.

Levin, A., Lin, C., \& Chu, C. (2002). Unit root tests in panel data: Asymptotic and finite-sample properties. Journal of Econometrics, 108(1), 1-24.

Loganathan, N., Sukemi, M.N., \& Sanusi, N.A. (2010). External debt and macroeconomics performance in Malaysia: Sustainable or not?. Global Economy and Finance Journal, 3(2), 122-132.

Maddala, G. S., \& Wu, S. (1999). A comparative study of unit root tests with panel data and a new simple test. Oxford Bulletin of Economics and Statistics, Special Issue, 631-652.

Mercan, M. (2014). Feldstein-Horioka hipotezinin AB-15 ve Türkiye ekonomisi için sınanması: Yatay kesit bağımlılı̆̆ altında yapısal kırılmalı dinamik panel veri analizi. Ege Akademik Bakış, 14(2), $1-23$.

Meriç, M. (2013). Devlet Borçları. Ankara: Şafak Matbaacılık.

Moon, H. R., \& Perron, B. (2004). Testing for a unit root in panels with dynamic factors. Journal of Econometrics, 122(1), 81-126.

Nguyen, A.T. (2018). The relationship between external debt, economic growth, unemployment and national expenditure in Vietnam: A vector autoregressive model approach. Journal of Economics and Management Sciences, 1(2), 129-140.

Oatley, T. (2010). Political institutions and foreign debt in the developing world. International Studies Quarterly, 54(1), 175-195.

Özler, S., \& Tabellini, G. (1991). External debt and political instability. National Bureau of Economic Research Working Paper, 3772, 1-42.

Özata, E. (2017). Determinants of external debt accumulation in Turkey: Evidence from an ARDL bound test approach. Journal of Business \& Economic Policy, 4(4), 134-143.

Peker, O., \& Bölükbaş, M. (2013). Türkiye'de dış borçlanmanın belirleyicileri: Ekonometrik bir analiz. Atatürk Üniversitesi İktisadi ve İdari Bilimler Dergisi, 27(2), 289-302. 
Pesaran, M. H. (2004). General diagnostic tests for cross section dependence in Panels. Cambridge University Working Paper, 435, 1-39.

Pesaran, M. H. (2006). Estimation and inference in large heterogeneous panels with a multifactor error structure. Econometrica, 76(4), 967-1012.

Pesaran, M. H. (2007). A simple panel unit root test in the presence of cross-section dependence. Journal of Applied Econometrics, 2(2), 265-312.

Pesaran, M. H., Ullah, A., \& Yamagata, T. (2008). A bias-adjusted LM test of error cross-section independence. The Econometrics Journal, 11(1), 105-127.

Phillips, P. C. B., \& Sul, D. (2003). Dynamic panel estimation and homogeneity testing under cross section dependence. The Econometrics Journal, 6(1), 217-259.

Sa'ad, S.A., Umar, A.T., Waziri, S.I., \& Maniam, G.S. (2017). External debt burden and its determinants in Nigeria: An ARDL cointegration technique. Journal of Economics and Sustainable Development, 8(12), 31-37.

Şak, N. (2015). Panel birim kök testleri. Stata ile panel veri modelleri, (Ed. Selahattin Güriş), İstanbul: Der Yayınları, 203-267.

Tatoğlu, F. Y. (2012). Panel veri ekonometrisi. İstanbul: Beta Yayıncılık.

Tatoğlu, F. Y. (2013). İleri panel veri analizi: Stata uygulamalı. İstanbul: Beta Yayıncılık.

Tiruneh, M.W. (2004). An empirical investigation into the determinants of external indebtedness. Prague Economic Papers, 3, 261-277.

Toktaş, Y., Altiner, A., \& Bozkurt, E. (2019). The relationship between Turkey's foreign debt and economic growth: An asymmetric causality analysis. Applied Economics, 51(26), 2807-2817.

Ün, T. (2015). Stata ile panel veri analizi. İçinde S. Güriş (ed.), Stata İle Panel Veri Modelleri (ss. 39-80). İstanbul: Der Yayınları.

Uzun, A. M., Karaköy, Ç., \& Emsen, Ö.S. (2012). Orta Asya ve Kafkaslarda borç-ekonomik büyüme ilişkileri. International Conference on Eurasian Economies, Almaty-Kazakhstan, 151-158.

Waheed, A. (2017). Determinants of external debt: A panel data analysis for oil and gas exporting and importing countries. International Journal of Economics and Financial Issues, 7(1), 234-240.

World Bank (2018). World Development Indicators. (Erişim Tarihi: 15.12.2018, https://datacatalog. worldbank.org/dataset/world-development-indicators).

Yamaçlı, D.S. (2015). Türkiye'de dış borçlanmanın belirleyicileri: Bazı kritik makroekonomik göstergelerin rolü. Finans Politik \& Ekonomik Yorumlar, 52(605), 19-40.

Yaşa, M. (1978). Devlet Borçları. Ankara: Ankara Üniversitesi Hukuk Fakültesi Yayınları. 